\title{
MODELS OF SUBSIDY ALLOCATION AMONG CITY DISTRICTS
}

\author{
Martin Dlouhý*
}

\begin{abstract}
:
Each year, a part of the budget of the City of Prague is allocated among its city districts in the form of subsidies. The objective of the City of Prague is to find such a set of criteria and such a set of relative weights that estimate the expected cost of local public administration best. The objective of each city district is subsidy maximization by influencing the criteria and weights. Two quantitative methods that set the weights without participation of decision makers are presented. The first method is based on the multiple-criteria decision making and the second one on the zero-sum gains DEA model. The illustrative calculations for the year 2012 are presented. An application of the multiple-criteria decision making model requires re-allocation of $8.3 \%$ of the total subsidy budget in comparison to the real subsidy values in the year 2012. An application of the zero-some gains DEA model requires re-allocation of $14.0 \%$ of the total subsidy to city districts. We are not able to offer any definitive answers about which allocation model is the best one, however, an analysis of the subsidy allocation process can help us in understanding the nature of the subsidy allocation problem and its potential weaknesses.
\end{abstract}

Keywords: subsidy allocation, data envelopment analysis, zero sum gains

JEL Classification: C44, C61, H71

\section{Introduction}

The City of Prague is the capital of the Czech Republic. The population is 1.2 million inhabitants (2011). The City of Prague has an administrative structure of three tiers. The highest tier is the Prague City Hall of the Capital City of Prague. Since 1990, the city has been divided into 57 self-governing city districts. The city districts differ in the size of population and territory. The city districts Prague 1 - Prague 22 are the so-called "large" city districts with high numbers of inhabitants (from 8,553 to 133,464) and are mostly located in the inner city. The districts Prague 23 - Prague 57 are the so-called "small" city districts with much lower numbers of inhabitants (from 283 to 10,306) and are mostly located in suburban areas. In total, less than $10 \%$ of Prague population live in the city districts Prague 23 - Prague 57. Since 2001, the 57 city districts have been grouped into 22 administrative districts, for state-administration purposes. One "large" city district in each administrative district has responsibility for providing services of

* University of Economics, Prague, Faculty of Informatics and Statistics, nám. W. Churchilla 4, CZ - 13067 Prague 3 (dlouhy@vse.cz). This research was funded by the Internal Grant Agency of the University of Economics, Prague, Project No. F4/16/2011 "Models of Operational and Financial Management". 
state administration for the entire administrative district. One has to distinguish whether by Prague 4 is meant one of the self-governing city districts Prague 1 - Prague 57 or one of the administrative districts Prague 1 - Prague 22.

Each year, a part of the budget of the City of Prague is allocated among its city districts. This allocation procedure is known as a "subsidy relation to city districts" (City of Prague, 2011). Various indicators can be used for subsidy allocation among the city districts that estimate the expected cost of local public administration. The political decision about the total subsidy and allocation criteria is made by the Prague City Assembly. During the current election period 2010-2014, four political parties are represented in the Prague City Assembly (TOP 09, ODS, ČSSD, and KSČM), but many other political parties and political movements are represented in the city district assemblies. Moreover, the representatives of the Prague City Assembly also form hidden coalitions based on the city districts they come from, irrespectively of their political membership. Not surprisingly, each year the subsidy allocation to city districts is a subject of fierce political struggle among and within the political parties and among the city districts. In such environment, it is very hard to find a compromise both based on objective facts and politically acceptable by all stakeholders. This process is surely an interesting topic for the theory of coalitional games (e.g. Osborne, 2004; Dlouhý, Fiala, 2009).

In brief, we have been summarizing the development of the subsidy allocation process for the large city districts Prague 1 - Prague 22 since 2001 to 2012. In 2001, the city districts received $30 \%$ of income tax paid by physical persons - entrepreneurs and in addition they received the so-called "criteria subsidy", which was based on five various criteria: population, territory, the number of pupils and students, the area of urban green, the road maintenance measured as area of roads in square meters. In 2002, the same model as in 2001 was used with some minor modifications. In 2003, the special solidarity model was exceptionally used due to the floods in August 2002. Between 2004 and 2006, the index method was used, which was derived from the annual growth of taxes collected by the City of Prague. The minimum average subsidy per inhabitant was introduced in 2004 at the level of 1,900 Czech korunas (CZK). This minimum was increased to 2,000 CZK in 2005 and to 2,100 CZK in 2006. Between 2007 and 2009, the subsidy allocation processes for the large city districts (Prague 1 - Prague 22) and the small city districts (Prague 23 - Prague 57) were separated and varied indicators were used for these two groups of city districts. This separation was used in the following years and is still valid. The allocation for the city districts Prague 1 - Prague 22 was based on three criteria: income tax paid by physical persons - entrepreneurs, population and territory. In 2010 , due to the worsened economic situation, the subsidies were indexed by $93.5 \%$ of 2009, but have to be minimally 2,400 CZK per inhabitant in each city district. In 2011, the 2009 criteria were used again and the minimum average subsidy 2,400 CZK per inhabitant was preserved.

In 2012, six criteria were used for the large city districts Prague 1 - Prague 22 (City of Prague, 2011). The city districts received $30 \%$ of income tax paid by physical 
persons - entrepreneurs (average 2008 - 2010), which made $9.5 \%$ of the total subsidy. The rest of the total subsidy was distributed according to five criteria: population in 2011 (with weight 30\%), territory in square kilometres (10\%), the number of pupils and students in the schools owned by the city district in 2011 (30\%), the area of urban green served by the city district (20\%), and the road maintenance measured as the area of the roads served by the city district in square meters $(10 \%)$. It may look as if the income tax has some special position in the allocation. However, it means nothing more than the real weights of criteria are as follows: income tax paid by physical persons - entrepreneurs (9.5\%), population in 2011 (27.1\%), territory in square kilometres $(9.0 \%)$, the number of pupils and students in the schools owned by the city district in $2011(18.1 \%)$, the area of urban green served by the city district (18.1\%), and the road maintenance measured as the area of the roads served by the city district in square meters $(9.0 \%)$.

For the small city districts Prague 23 - Prague 57 without responsibility for state administration, a little bit different subsidy allocation model was used. Because the allocation processes for the large and small city districts differ from each other, we will focus, for simplicity, on the large city districts Prague 1 - Prague 22 that are responsible for both self-governing public administration and state administration. In chapter two, we present two quantitative methods of allocation, and in chapter three, we carry out illustrative calculations for the large city districts.

\section{Methods}

From the mathematical point of view, the subsidy allocation is a typical problem of multiple-criteria decision making. The objective of the City of Prague is to find such a set of criteria and such a set of relative weights that estimate the expected cost of local public administration best. The rational objective of a city district is subsidy maximization. However, the city district is a part of a larger organization (The City of Prague) in which the value of total subsidy is fixed. Once the value of total subsidy is set by the City of Prague, a higher value of subsidy for one city district can be achieved only by lower subsidies for the other city districts. The number of feasible solutions is infinite and various stakeholders try to manipulate the criteria included in the calculation and their relative weights. From this perspective, an allocation method that eliminates the "subjective" influences on the weight setting should be preferred. Here we present two quantitative methods that set the weights without the participation of decision makers. The first allocation method is based on multiple-criteria decision making (Section 2.1) and the second one is a specific DEA model (Section 2.2).

\subsection{Multiple-criteria decision making}

The first quantitative method is based on the principles of multiple-criteria decision making (see e.g. Fiala, Jablonský, Maňas, 1994; Jablonský, Dlouhý, 2004; Fotr, Švecová, 2010). Let us have $m$ city districts and $n$ allocation criteria. In this case, the values are 
$m=22$ and $n=6$. The real values for city district $i$ in each criteria $j$ are $y_{\mathrm{ij}}$. The relative proportion of city district $i$ in dimension $j$ on the total sum for all city districts is denoted $r_{\mathrm{ij}}$, and is calculated as

$$
r_{i j}=y_{i j} / \sum_{i=1}^{m} y_{\mathrm{ij}} \text {. }
$$

The total budget subsidy which is allocated among city districts is denoted $B$. The subsidy to city district $i$ is denoted $s_{\mathrm{i}}$. Let us further suppose that each criterion will have the minimum weight at least $5 \%$. The best case scenario, an upper limit of the subsidy for the $i$ th city district $u_{\mathrm{i}}$, is that subsidy will be calculated as

$$
u_{i}=\left((1-0.05 n) \max _{j} r_{i j}+0.05 \sum_{\mathrm{j}=1}^{\mathrm{n}} r_{i j}\right) B .
$$

On the other hand, the worst case scenario, a lower limit of the subsidy $l_{\mathrm{i}}$, is calculated as

$$
l_{i}=\left((1-0.05 n) \min _{j} r_{i j}+0.05 \sum_{\mathrm{j}=1}^{\mathrm{n}} r_{i j}\right) B .
$$

One of the rational conditions for resource allocation is that the level of minimal satisfaction in comparison to lower and upper subsidy limits is maximized. This can be expressed as

$$
\frac{s_{i}-l_{i}}{u_{i}-l_{i}} \geq a_{i} \quad i=1,2, \ldots, m,
$$

where $a$ is the maximal level of minimal satisfaction that range between 0 and 1 . Such a formulation is a distance function known in multi-objective programming. In this case the solution can be obtained from the following linear programme:

$$
\begin{aligned}
& \max \quad a \\
& \text { subject to } \\
& s_{i}-l_{i}-a\left(u_{i}-l_{i}\right) \geq 0, \quad i=1,2, \ldots, m, \\
& \sum_{i=1}^{m} s_{i}=B \\
& s_{i} \geq 0, \quad i=1,2, \ldots, m, \\
& a \geq 0 .
\end{aligned}
$$

The sum of $l_{\mathrm{i}}$ gives us interesting information about what part of total subsidy $B$ is allocated irrespectively of the real values of weights. On the other hand, the sum of $u_{\mathrm{i}}$, which is greater than $B$, represents the sum of ideal (upper) values for each city district. In other words, by how much the City of Prague should increase the original total budget for subsidies to meet all expectations of city districts. By comparing the distances between the available budget $B$ and the sum of lower subsidy limits and between the sums of upper and lower subsidy limits one obtains the value $a$ directly from: 


$$
a=\frac{B-\sum_{i=1}^{m} l_{i}}{\sum_{i=1}^{m} u_{i}-\sum_{i=1}^{m} l_{i}} .
$$

The value of subsidy for $i$ th city district is then calculated from:

$$
s_{i}=l_{i}+a\left(u_{i}-l_{i}\right) \quad i=1,2, \ldots, m .
$$

It is not, therefore, necessary to solve linear programming problem (5); it is sufficient to carry out a few calculations in the spreadsheet:

1. Calculate $u_{\mathrm{i}}, l_{\mathrm{i}}$ from equations (2) and (3);

2. Calculate value $a$ from (6);

3. Calculate subsidies $s_{\mathrm{i}}$ from (7).

\subsection{Data envelopment analysis}

Data envelopment analysis (DEA) evaluates technical efficiency of a production unit with the help of mathematical programming. DEA is based on the idea to specify the production frontier as the most pessimistic piecewise linear envelopment of the data and to construct technical efficiency measures based on radial uniform contractions or expansions from inefficient observations to the production frontier. The DEA model for multiple inputs and outputs was formulated and solved by Charnes, Cooper, and Rhodes (1978). Since 1978 a great variety of DEA models with various applications, extensions and modifications has been published (Charnes, Cooper, Lewin, Seiford, 1994; Cooper, Seiford, Tone, 2000; Dlouhý, 2001; Jablonský, Dlouhý, 2004; Dlouhý, Jablonský, Novosádová, 2007).

Each production unit allocates its resources into a number of inputs to produce various outputs. Data envelopment analysis uses quantities of inputs consumed and outputs produced to calculate the relative technical efficiency of a production unit. The relative technical efficiency of the production unit is defined as the ratio of its total weighted output to its total weighted input or, vice versa, as the ratio of its total weighted input to its total weighted output.

Data envelopment analysis allows each production unit to choose its own weights of inputs and outputs in order to maximize its efficiency score. A technically efficient production unit is able to find such weights of inputs and outputs that it lies on the production frontier. The production frontier represents the maximum amounts of output that can be produced by given amounts of inputs (in the output maximization model) or, alternatively, the minimum amounts of inputs required to produce the given amounts of outputs (in the input minimization model). The mathematical formulation of the inputoriented constant-returns-to-scale DEA model is: 


$$
\begin{array}{ll}
\operatorname{maximize} \quad & \frac{\sum_{i=1}^{r} u_{\mathrm{i}} y_{\mathrm{iq}}}{\sum_{j=1}^{m} v_{\mathrm{j}} x_{\mathrm{jq}}}, \\
\text { subject to } \quad & \frac{\sum_{i=1}^{r} u_{\mathrm{i}} y_{\mathrm{ik}}}{\sum_{j=1}^{m} v_{\mathrm{j}} x_{\mathrm{jk}}} \leq 1, \quad k=1,2, \ldots, n, \\
& u_{\mathrm{i}} \geq \varepsilon, i=1,2, \ldots, r, \\
& v_{\mathrm{j}} \geq \varepsilon, j=1,2, \ldots, m,
\end{array}
$$

where $x_{\mathrm{jk}}$ is the amount of input $j$ used by production unit $k, y_{\mathrm{ik}}$ is the amount of $i$ th output produced by production unit $k$, weights $u_{\mathrm{i}}$ and $v_{\mathrm{j}}$ are variables in the DEA model, $\varepsilon$ is infinitesimal constant. The value of objective function is the efficiency score of unit $q$. To solve the program (8) by linear programming, the program has to be transformed to the linear form:

maximize

$$
\sum_{i=1}^{r} u_{\mathrm{i}} y_{\mathrm{iq}}
$$

subject to

$$
\begin{aligned}
& \sum_{i=1}^{r} u_{\mathrm{i}} y_{\mathrm{ik}} \leq \sum_{j=1}^{m} v_{\mathrm{j}} x_{\mathrm{jk}}, \quad k=1,2, \ldots, n, \\
& \sum_{j=1}^{m} v_{\mathrm{j}} x_{\mathrm{jq}}=1, \\
& u_{\mathrm{i}} \geq \varepsilon, i=1,2, \ldots, r, \\
& v_{\mathrm{j}} \geq \varepsilon, j=1,2, \ldots, m .
\end{aligned}
$$

The DEA model (9) has to be formulated and solved for each production unit $q=1,2, \ldots, n$. Specialised DEA software or MS Excel applications are available at present, which makes it easy to carry out all necessary calculations.

How can data envelopment analysis help us with the subsidy allocation problem? The objective of each city district is to use the available inputs (criteria included in subsidy calculation) in order to maximize the output (subsidy). The total subsidy distributed among the city districts is fixed. The money allocated to one city district additionally means that the subsidies to the other city districts have to be reduced. For this type of resource allocation problem, with the total sum of inputs or outputs being fixed, the so-called zero-sum-gains DEA model (ZSG-DEA) was developed (Lins, Gomes, et al., 2003; Gomes, Da Silva e Souza, 2010; Dlouhý, 2012). The idea of this specific DEA model is to re-allocate inputs or outputs in such a way that all production units (in this case city districts) will become technically efficient. For the output-oriented ZSG-DEA 
model, the following equation is valid:

$$
h_{Z S G i}=h_{D E A i}\left(1-\frac{\sum_{j \in W} y_{\mathrm{j}}\left[\left(h_{D E A i} / h_{D E A j}\right) h_{Z S G i}-1\right]}{\sum_{j \notin W} y_{\mathrm{j}}}\right) \text {, }
$$

where $h_{\mathrm{ZSGi}}$ is the technical efficiency score of production unit $i$ in the ZSG-DEA model, $h_{\text {DEAi }}$ is the efficiency score of production unit $i$ in the traditional DEA model, and $W$ is a set of inefficient production units.

In the ZSG-DEA model with one output (in this case the value of subsidy), the ZSG-DEA model can be simplified. Suppose that the City of Prague will allocate a constant budget $B$ among $n$ city districts based on given inputs. In the initial output-oriented DEA model, regardless of the input level, the amount $B / n$ is allocated to each city district. Then we solve a DEA model with the single constant output and six inputs and obtain values $h_{\text {DEAi}}$. The final projection of output (subsidy) calculated as $h_{\text {DEAi }} / \Sigma h_{\text {DEAi }}$ is ZSG-DEA efficient. This solution can be shown to be invariant under the scale and orientation of the DEA model (Gomes, Da Silva e Souza, 2010).

\section{Results}

The data on six criteria used for the 2012 subsidy allocation among the large city districts Prague 1 - Prague 22 are presented in Table 1. The data come from the Resolution of the City Council No. 1922/2011 (City of Prague, 2011). As we have already mentioned, a different allocation model was used for the small city districts Prague 23 - Prague 57, therefore, for simplicity, we will focus on the large city districts Prague 1 - Prague 22 only. However, it is no problem to use the presented methods in case of small city districts Prague 23 - Prague 57 analogically.

The results of the multiple-criteria decision making model, which was described in Section 2.1, are presented in Table 2. The values of $l_{\mathrm{i}}, u_{\mathrm{i}}$, and $s_{\mathrm{i}}$ are expressed as percentages by setting the total subsidy $B=100$. The sum of $l_{i}$ gives us the information that the allocation of $61 \%$ of the total subsidy $B$ is determined irrespectively of weights. In other words, the allocation process is about distributing of $39 \%$ of $B$. The differences $\left(u_{\mathrm{i}}-l_{\mathrm{i}}\right)$ show us the potential impact of changes of weights on the city districts. The greatest change from the total subsidy budget perspective is expected for city districts Prague 20 and Prague 1. On the other hand, the proportion of subsidies of city district Prague 17 is not influenced by real weights of criteria. The value of satisfaction level $a$ is calculated from (100-61.04)/ (86.39) and is 0.451 . Then, the values of $s_{\mathrm{i}}$ were calculated from formula (7). 
DOI: 10.18267/j.pep.475

Table 1

Description of Criteria, Prague 1 - Prague 22

\begin{tabular}{|l|c|c|c|c|c|r|}
\hline District & $\begin{array}{c}\text { Population } \\
\mathbf{2 0 1 1}\end{array}$ & $\begin{array}{c}\text { Territory in } \\
\mathbf{k m}^{\mathbf{2}}\end{array}$ & $\begin{array}{c}\text { Students } \\
\mathbf{2 0 1 1}\end{array}$ & $\begin{array}{c}\text { Urban Green } \\
\text { (ha) }\end{array}$ & $\begin{array}{c}\text { Roads } \\
\mathbf{2 0 1 1}\end{array}$ & $\begin{array}{c}\text { Income } \\
\text { Tax }\end{array}$ \\
\hline Prague 1 & 30965 & 5.51 & 2828 & 43.20 & 13478 & 82962 \\
\hline Prague 2 & 52326 & 4.18 & 4117 & 58.00 & 8820 & 78354 \\
\hline Prague 3 & 76378 & 6.48 & 5076 & 63.70 & 33411 & 64823 \\
\hline Prague 4 & 133464 & 24.20 & 10983 & 261.50 & 266774 & 121682 \\
\hline Prague 5 & 86696 & 27.50 & 6297 & 86.60 & 200588 & 85308 \\
\hline Prague 6 & 103170 & 41.56 & 9369 & 209.00 & 503219 & 134268 \\
\hline Prague 7 & 43939 & 7.12 & 1950 & 8.85 & 31092 & 33383 \\
\hline Prague 8 & 109098 & 21.80 & 8749 & 204.60 & 147511 & 63319 \\
\hline Prague 9 & 55628 & 13.31 & 3314 & 120.00 & 139641 & 18258 \\
\hline Prague 10 & 114211 & 18.60 & 7355 & 145.00 & 206445 & 79252 \\
\hline Prague 11 & 79302 & 9.79 & 7082 & 227.10 & 323164 & 37172 \\
\hline Prague 12 & 56166 & 23.32 & 4913 & 136.00 & 635851 & 27844 \\
\hline Prague 13 & 61979 & 13.23 & 6607 & 166.40 & 510290 & 31834 \\
\hline Prague 14 & 47277 & 13.53 & 4079 & 91.40 & 395765 & 13302 \\
\hline Prague 15 & 31616 & 10.25 & 2667 & 62.10 & 169183 & 14254 \\
\hline Prague 16 & 8553 & 9.30 & 919 & 11.50 & 250908 & 6170 \\
\hline Prague 17 & 25697 & 3.25 & 2105 & 33.20 & 132145 & 10190 \\
\hline Prague 18 & 17539 & 5.61 & 1650 & 19.50 & 200105 & 2674 \\
\hline Prague 19 & 6754 & 6.00 & 687 & 22.70 & 137619 & 1923 \\
\hline Prague 20 & 15291 & 16.94 & 1940 & 46.60 & 672902 & 12437 \\
\hline Prague 21 & 10485 & 10.15 & 1117 & 33.60 & 310321 & 8605 \\
\hline Prague 22 & 8983 & 15.62 & 1103 & 20.40 & 264615 & 5219 \\
\hline
\end{tabular}

Source: Resolution No. 1922/2011, Appendix 2 (City of Prague, 2011) 
Table 2

Results of Multiple-Criteria Decision Making Model in \%

\begin{tabular}{|l|c|c|c|c|}
\hline District & $\boldsymbol{I}_{\mathbf{i}}$ & $\boldsymbol{u}$ & $\boldsymbol{u}_{\mathbf{i}}-\boldsymbol{I}_{\mathbf{i}}$ & $\boldsymbol{s}_{\mathbf{i}}$ \\
\hline Prague 1 & 1.10 & 7.15 & 6.05 & 3.83 \\
\hline Prague 2 & 1.19 & 6.95 & 5.77 & 3.79 \\
\hline Prague 3 & 1.65 & 6.09 & 4.44 & 3.65 \\
\hline Prague 4 & 6.43 & 12.19 & 5.76 & 9.03 \\
\hline Prague 5 & 4.52 & 8.39 & 3.87 & 6.27 \\
\hline Prague 6 & 9.43 & 13.36 & 3.93 & 11.20 \\
\hline Prague 7 & 0.93 & 3.25 & 2.32 & 1.98 \\
\hline Prague 8 & 4.10 & 9.16 & 5.06 & 6.39 \\
\hline Prague 9 & 2.51 & 5.20 & 2.69 & 3.72 \\
\hline Prague 10 & 4.74 & 8.94 & 4.20 & 6.63 \\
\hline Prague 11 & 4.14 & 9.58 & 5.45 & 6.59 \\
\hline Prague 12 & 4.02 & 9.94 & 5.93 & 6.69 \\
\hline Prague 13 & 4.25 & 8.29 & 4.04 & 6.07 \\
\hline Prague 14 & 2.28 & 6.27 & 3.99 & 4.08 \\
\hline Prague 15 & 1.89 & 3.16 & 1.27 & 2.46 \\
\hline Prague 16 & 0.91 & 3.69 & 2.77 & 2.16 \\
\hline Prague 17 & 1.27 & 2.19 & 0.92 & 1.68 \\
\hline Prague 18 & 0.69 & 3.02 & 2.32 & 1.74 \\
\hline Prague 19 & 0.50 & 2.09 & 1.59 & 1.21 \\
\hline Prague 20 & 2.14 & 9.71 & 7.57 & 5.55 \\
\hline Prague 21 & 1.30 & 4.59 & 3.29 & 2.78 \\
\hline Prague 22 & 1.06 & 4.22 & 3.17 & 2.49 \\
\hline Total Sum & $\mathbf{6 1 . 0 4}$ & $\mathbf{1 4 7 . 4 3}$ & $\mathbf{8 6 . 3 9}$ & $\mathbf{1 0 0 . 0 0}$ \\
\hline
\end{tabular}

Source: own calculation

The real values of subsidies in thousands of CZK and results of the multiple-criteria decision making (MCDM) model and the output-oriented ZSG-DEA model are presented in Table 3. The real values of subsidies are presented before the application of the average minimum subsidy per inhabitant rule (CZK 2,400 in 2012) in order to show the results of the original six-criteria allocation model. The total subsidy to city districts allocated by the current model used by the City of Prague was CZK 2,934 million. After this initial allocation, the average allocation per inhabitant was checked and nine city districts (Prague 2, 3, 4, 5, 7, 8, 9, 10. and 17) obtained additional subsidies amounting in total CZK 196 million to comply with the minimum CZK 2,600 per inhabitant rule (City of Prague, 2011). The final total subsidy to city districts increased to CZK 3,130 million. 
Table 3

Subsidies to City Districts in 2012 (in thousands CZK) in Comparison with Two Alternative Allocation Models (2012=100\%)

\begin{tabular}{|l|r|r|r|r|r|}
\hline District & $\begin{array}{c}\text { Real values } \\
\text { of subsidy }\end{array}$ & $\begin{array}{c}\text { MCDM } \\
\text { in \% }\end{array}$ & $\begin{array}{c}\text { MCDM } \\
\text { in CZK }\end{array}$ & $\begin{array}{c}\text { ZSG-DEA } \\
\text { in } \%\end{array}$ & $\begin{array}{c}\text { ZSG-DEA } \\
\text { in CZK }\end{array}$ \\
\hline Prague 1 & 85821 & 131 & 112402 & 72 & 62104 \\
\hline Prague 2 & 112024 & 99 & 111104 & 55 & 62104 \\
\hline Prague 3 & 136847 & 78 & 107179 & 55 & 74836 \\
\hline Prague 4 & 318767 & 83 & 264819 & 79 & 251889 \\
\hline Prague 5 & 192130 & 96 & 183920 & 97 & 185970 \\
\hline Prague 6 & 301462 & 109 & 328632 & 113 & 340284 \\
\hline Prague 7 & 74170 & 78 & 58033 & 84 & 62104 \\
\hline Prague 8 & 243852 & 77 & 187348 & 64 & 155944 \\
\hline Prague 9 & 119598 & 91 & 109210 & 73 & 86808 \\
\hline Prague 10 & 225298 & 86 & 194593 & 86 & 194419 \\
\hline Prague 11 & 205774 & 94 & 193498 & 81 & 167212 \\
\hline Prague 12 & 172568 & 114 & 196229 & 161 & 278090 \\
\hline Prague 13 & 184843 & 96 & 178100 & 107 & 197649 \\
\hline Prague 14 & 123903 & 97 & 119760 & 136 & 168486 \\
\hline Prague 15 & 80685 & 89 & 72186 & 116 & 93695 \\
\hline Prague 16 & 38244 & 166 & 63446 & 162 & 62104 \\
\hline Prague 17 & 55575 & 89 & 49434 & 112 & 62104 \\
\hline Prague 18 & 45784 & 112 & 51106 & 136 & 62104 \\
\hline Prague 19 & 28436 & 125 & 35591 & 218 & 62104 \\
\hline Prague 20 & 88925 & 183 & 162914 & 153 & 136005 \\
\hline Prague 21 & 51185 & 159 & 81621 & 185 & 94838 \\
\hline Prague 22 & 48170 & 151 & 72932 & 152 & 73208 \\
\hline Total Sum & 2934057 & 100 & 2934057 & 100 & 2934057 \\
\hline
\end{tabular}

Source: own calculation

The results of the MCDM and ZSG-DEA models are presented in thousands CZK and in percentages to show clearly the impact of these allocation models on the level of subsidy allocated to each city district (Table 3 ). In both subsidy allocation models, city districts Prague $6,12,16,18,19,20,21$, and 22 benefit from subsidy distribution suggested by any of two models. City district Prague 19 is an extreme case because its budget should be more than doubled according to the ZSG-DEA model. On the other hand, city districts Prague 2 and Prague 3, and Prague 8 would be the greatest losers in case of application of the ZSG-DEA model, and city districts Prague 3, Prague 7, and Prague 8 in case 
of application of the MCDM model. An application of the MCDM model requires re-allocation of $8.3 \%$ of the total subsidy budget in comparison to the real subsidy values in the year 2012. An application of the ZSG-DEA model requires re-allocation of $14.0 \%$ of the total subsidy to city districts. The ZSG-DEA value is greater as we have used the original version of the ZSG-DEA model without weight restriction, so this model offers greater flexibility. In reality of political decision making, the changes in subsidies will be much lower as one may expect more restrictions on weights.

\section{Conclusion}

A part of the budget of the City of Prague is allocated among the city districts in the form of subsidies each year. We have described the subsidy allocation problem and showed the problem the Prague City Assembly has to face in order to determine an optimal set of criteria and their weights. We have presented two quantitative methods that set the weights without direct participation of decision makers. The first subsidy allocation method is based on the multiple-criteria decision making and the second one on the zero-sum gains DEA model. All the calculations we have presented in this study have to be seen as illustrative because we did not include any additional information about the significance of individual criteria. For example, it can be argued that the minimum weight for population should be at least 10, 20 or 30\%, not 5\% as in the MCDM or even $0 \%$ in the ZSG-DEA model without weight restrictions. On the other hand, the weight for road maintenance is not expected to be greater than 10 or $15 \%$.

An application of the MCDM model requires re-allocation of $8.3 \%$ of the total subsidy budget in comparison to the real subsidy values in the year 2012. An application of the ZSG-DEA model requires re-allocation of $14.0 \%$ of the total subsidy to city districts. It seams that six-criteria allocation model can be more favourable for suburban districts (Prague 6, 12, 16, 18, 19, 20, 21, and 22) that have relatively higher values in criteria as territory, urban green, and roads served. The city districts located in inner city may benefit from reducing the number of criteria to population (Table 4). However, any change in the set of criteria may lead to a potential political conflict.

We are not able to offer any definitive answers about which subsidy allocation model is the best one, however, a mathematical analysis of the subsidy allocation process can surely help us in understanding the nature of the subsidy allocation problem and its potential weaknesses. Such understanding can help us at least in avoiding bad allocation models based on political manipulation. 
Table 4

Subsidies to City Districts in 2012 (in thousands CZK) in Comparison with Allocation per Inhabitant in \% (2012=100\%) and in thousands CZK

\begin{tabular}{|l|r|r|r|}
\hline District & $\begin{array}{c}\text { Real values } \\
\text { of subsidy }\end{array}$ & in \% & in CZK \\
\hline Prague 1 & 85821 & 90 & 77288 \\
\hline Prague 2 & 112024 & 117 & 130604 \\
\hline Prague 3 & 136847 & 139 & 190637 \\
\hline Prague 4 & 318767 & 105 & 333122 \\
\hline Prague 5 & 192130 & 113 & 216391 \\
\hline Prague 6 & 301462 & 85 & 257509 \\
\hline Prague 7 & 74170 & 148 & 109671 \\
\hline Prague 8 & 243852 & 112 & 272306 \\
\hline Prague 9 & 119598 & 116 & 138846 \\
\hline Prague 10 & 225298 & 127 & 285067 \\
\hline Prague 11 & 205774 & 96 & 197936 \\
\hline Prague 12 & 172568 & 81 & 140189 \\
\hline Prague 13 & 184843 & 84 & 154698 \\
\hline Prague 14 & 123903 & 95 & 118002 \\
\hline Prague 15 & 80685 & 98 & 78913 \\
\hline Prague 16 & 38244 & 56 & 21348 \\
\hline Prague 17 & 55575 & 115 & 64139 \\
\hline Prague 18 & 45784 & 96 & 43777 \\
\hline Prague 19 & 28436 & 59 & 16858 \\
\hline Prague 20 & 88925 & 43 & 38166 \\
\hline Prague 21 & 51185 & 51 & 26170 \\
\hline Prague 22 & 48170 & 47 & 22421 \\
\hline Total Sum & 2934057 & 100 & 2934057 \\
\hline
\end{tabular}

Source: own calculation 


\section{References}

Charnes, A., Cooper, W. W., Lewin, A. Y, Seiford, L. M. (Eds) (1994), Data Envelopment Analysis: Theory, Methodology and Applications. Boston: Kluwer Academic Publishers.

Charnes, A., Cooper, W. W., Rhodes, E. (1978), "Measuring the Inefficiency of Decision Making Units." European Journal of Operational Research 2, pp. 429-444.

City of Prague. (2011), "Resolution of the City Council No. 1922 on Proposal of Budget of the City of Prague for Year 2012, of Subsidy Relations to City Districts of the City of Prague for Year 2012, and Budget Outlook till 2017." Prague: Prague City Council 29. 11. 2011.

Cooper, W. W., Seiford, L.W., Tone, K. (2000), Data Envelopment Analysis. Boston: Kluwer Academic Publishers.

Dlouhý, M. (2001), "Matematický model restrukturalizace odvětví a firmy." Politická ekonomie, Vol. 49, No. 4, pp. 540-546.

Dlouhý, M., Jablonský, J., Novosádová, I. (2007), "Využití analýzy obalu dat pro hodnocení efektivnosti českých nemocnic." Politická ekonomie, Vol. 54, No. 1, pp. 60-71.

Dlouhý, M., Fiala, P. (2009), Úvod do teorie her. 2nd Edition. Prague: University of Economics.

Dlouhý, M. (2012), "Efficiency and Resource Allocation within a Hierarchical Organization." In Proceedings of 30th International Conference Mathematical Methods in Economics 2012, pp. 112-116. Karviná: Silesian University in Opava.

Fiala, P., Jablonský, J., Maňas, M. (1994), Vicekriteriální rozhodování. Prague: University of Economics.

Fotr, J., Švecová, L., et al. (2010), Manažerské rozhodování: postupy, metody, nástroje. Prague: Ekopress.

Gomes, E. G., Da Silva e Souza, G. (2010), "Allocating Financial Resources for Competitive Projects Using a Zero Sum Gains DEA Model." Engevista, Vol. 12, No. 1, pp. 4-9.

Jablonský, J., Dlouhý, M. (2004), Modely hodnocení efektivnosti produkčních jednotek. Prague: Professional Publishing.

Lins, M. P. E., Gomes, E. G., Soares De Mello, J. C. C. B., Soares De Mello, A. J. R. (2003),"Olympic Ranking Based on a Zero Sum Gains DEA Model." European Journal of Operational Research, Vol. 148, No. 2, pp. 312-322.

Osborne, M. J. (2004), An Introduction to Game Theory. Oxford: Oxford University Press. 